\title{
ヒューマノイドロボットの押し操作における歩行動作
}

\author{
原田研 介* 梶田秀 司* 金 広 文 男* 藤 原 清 司* \\ 金子 健 二* 横 井 一 仁* 比留川 博 久*
}

\section{Walking Motion for Pushing Manipulation by a Humanoid Robot}

Kensuke Harada*, Shuuji Kajita*, Fumio Kanehiro*, Kiyoshi Fujiwara*,

Kenji Kaneko*, Kazuhito Yokoi* and Hirohisa Hirukawa*

\begin{abstract}
This paper discusses the pushing manipulation of an object by a humanoid robot. We generate the walking pattern for the pushing task by modifying the desired ZMP trajectory of the walking pattern for a humanoid robot whose hands do not contact with an object. For the modified walking pattern, we analyze whether or not the robot can keep the dynamical balance by considering both the ZMP and the walking velocity. The validity of the proposed method is confirmed by some simulation results. We further consider extending the proposed algorithm by separating the walking phase and the pushing phase.
\end{abstract}

Key Words: Humanoid Robot, ZMP, Pushing Manipulation

\section{1. 緒}

ヒトのように 2 本の腕と 2 本の脚を備えたロボット（ヒュー マノイドロボット) は, ヒトと同じ環境でヒトと協調しながら作 業を行うことが期待されている。このとき，ヒューマノイドロ ボットは手先で対象物や環境と接触しながら歩行を行うといっ た，腕と脚を併用した動作を実現することが必要となる．腕と 脚を併用する作業の例として，ヒューマノイドロボットが床の 上に置かれた比較的大きな対象物を別の場所に移動させる場合 を考えてみよう。このような作業を，対象物をいったん持ち上げ てから別の場所に移動させるピックアンドプレースによって実 行する場合, ヒューマノイドは大きな対象物を持ち上げること でバランス維持が困難になることが予想できる。この場合，対 象物を床に置いた状態のまま, 脚と腕を協調させて対象物を押 すことで，対象物を目標の位置／姿勢に収束させる方が効果的 であると考えられる。よって，本研究ではヒューマノイドによ る対象物の押し操作に着目する。

押し操作の場合, ヒューマノイドの手先が対象物と接触する ことによって，手先には反力が生じる。この反力の影響により， 手先に反力を受けてない場合と比較して ZMP の位置が変位す ることが予想できる。ここで，押し操作における ZMP に着目 してみよう. Fig. 1 に, ヒューマノイドによる押し操作の一例

原稿受付 2003 年 4 月 3 日

*産業技術総合研究所

*National Institute of Advanced Industrial Science and Technology

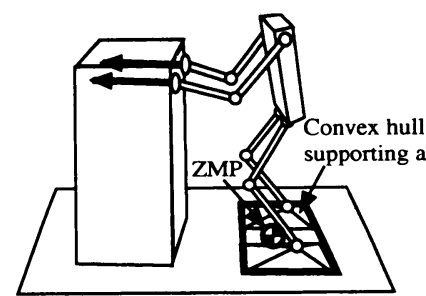

(a) Manipulation with small pushing force

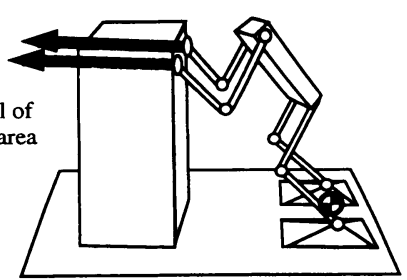

(b) Manipulation with large pushing force
Fig. 1 Pushing manipulation by a humanoid robot

を示す。まず，底面の摩擦係数が小さく比較的軽い対象物に対 して押し操作を実行する場合を考える（Fig. 1(a)）。このよう な対象物を押す場合, 対象物と接触することによって手先に発 生する反力は比較的小さいため, 手先反力の影響による ZMP の変位も小さいことが予想できる，このとき，手先に反力が加 わらないと仮定して生成した歩行動作パターンをロボットに適 用することで, ヒューマノイドロボットは ZMP を足裏支持領 域内に保ちながら，転倒することなしに押し操作を実行できる と考えられる。そそれに対して，底面の摩擦係数が大きく重い対 象物に対して押し操作を行う場合を考える（Fig. 1(b))。この ような対象物を押す場合, 手先に発生する反力の影響で, ZMP は大きく変位することになる.つまり，手先に反力が加わらな いと仮定して生成した歩行動作パターンを何らかの方法で変更 したり，あるいは手先反力を考慮して歩行動作パターンを生成 することが必要となる。 
本論文では、ヒューマノイドロボットの手先が対象物と接して いる場合の ZMP に関する考察を行い，この考察をもとにヒュー マノイドロボットによる押し操作を実現することを考える．提 案する手法では，手先に反力を受けていないロボットに対する 歩行パターンにおいて，目標 ZMPを一定量だけ変更すること を考える。このようにして生成された歩行パターンに対して， ZMP と歩行速度の観点より，ロボットが動的平衡を保てるかと うかを吟味する．2 章において関連研究を述べた後， 3 章では 手先反力と ZMP の位置変位との関係式を導出する。またこの 関係を下に，押し操作に対する歩行パターンについて考察する。 4 章では，提案する手法の有効性をシミュレーションによって 確認する。最後に，5章ではより安定に押し操作を行うことを 目指して，対象物を押すフェーズと歩くフェーズを分離する手 法について議論する。

\section{2. 関 連 研 究}

ヒューマノイドロボットが腕で作業しながら移動するような, 腕と脚の協調に関する研究として, 井上ら [1] は腕の可操作性 を考慮してロボットの姿勢を決定する手法を提案し, Yoshida ら [2] はロボットの姿勢の手先反力に対するロバスト性につい て議論した. Inoue ら [3] はヒューマノイドロボットを実環境で 応用することを目指して HRP (Humanoid Robotics Project) を組織した，HRPの一環として, Kanekoら [4]は HRP-2P と 呼ばれるヒューマノイドロボットを開発した。また，HRPで は，脚と腕を協調させる作業として，ヒトとヒューマノイドロ ボットとのパネルの協調搬送作業や [5], 寝た状態からの起き上 がり [6] 等が実現されている. Hirai ら [7] はヒューマノイドロ ボットを開発した。開発されたロボットを用いて，脚と腕を協調 させる作業として，下にタイヤのついた台車を押す作業 [8]を実 現した．北川ら [9]は座っている椅子の上に手をつきながら，起 き上がる動作をシミュレーション上で実現した。しかしながら， ヒューマノイドによって床の上に置かれた対象物を押し操作に よりマニピュレーションする研究は現在まで行われていない.

2 足歩行ロボットの歩行動作のパターン生成に関する研究と して, 高西 [10] は ZMP 方程式をフーリ工級数展開することに より，歩行動作パターンを生成した．Kajita らはロボットを倒 立振り子で近似することで, 二次元 [11] や三次元 [12] の歩行動 作を生成した．Nishiwaki ら [13] [14] は ZMP 方程式の離散化 に基づいた実時間動作生成法を提案した。しかしながら，手先 に反力が加わる場合の歩行について論じた研究はない.

また，対象物の押し操作に関する研究は従来より多く行われ ている，例えば, Mason ら [15] や, Lynch [16] は対象物と床 面との間に存在する摩擦力を考慮して，対象物を望みの方向に 押し操作で移動させる研究を行った. Harada ら [17] は複数対 象物の押し操作について議論した。

\section{3. 定式化}

\section{1 ZMP}

Fig. 2 に，ヒューマノイドロボットが手先で対象物と接触 するモデルを示す． $\Sigma_{R}$ は基準座標系であり， $\Sigma_{i}$ は第 $i$ リン ク $(i=1, \cdots, n)$ に固定された座標系を表す． $\Sigma_{R}$ に関する

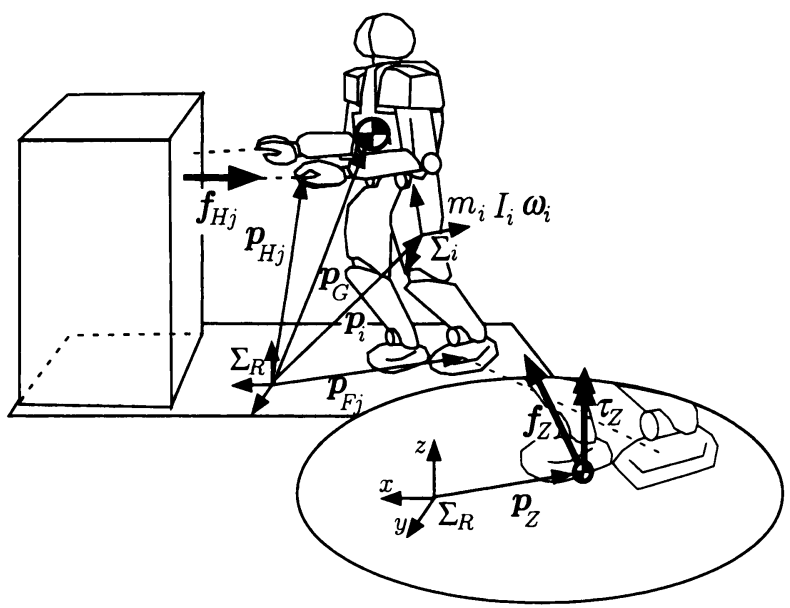

Fig. 2 Model of the system

位置ベクトルとして, $\boldsymbol{p}_{H j}\left(=\left[\begin{array}{lll}x_{H j} & y_{H j} & z_{H j}\end{array}\right]^{T}\right)(j=1,2)$ は 手先, $\boldsymbol{p}_{F j}\left(=\left[\begin{array}{lll}x_{F j} & y_{F j} & z_{F j}\end{array}\right]^{T}\right)(j=1,2)$ は足裏の支持領域 における代表点, $\boldsymbol{p}_{i}\left(=\left[\begin{array}{lll}x_{i} & y_{i} & z_{i}\end{array}\right]^{T}\right)$ は $\Sigma_{i}$ 原点を表す。また， $\boldsymbol{p}_{G}\left(=\left[\begin{array}{lll}x_{G} & y_{G} & z_{G}\end{array}\right]^{T}\right)$ はロボットの重心を表す位置ベクトルで あり, $\boldsymbol{p}_{G}=\sum_{i=1}^{n} m_{i} \boldsymbol{p}_{i} / \sum_{i=1}^{n} m_{i}$ のように定義される.さら に, $\boldsymbol{p}_{Z}\left(=\left[\begin{array}{lll}x_{Z} & y_{Z} & z_{Z}\end{array}\right]^{T}\right)$ は床面上でZMP の位置を表すべクト ルである. $\boldsymbol{f}_{H j}\left(=\left[\begin{array}{lll}f_{H j x} & f_{H j y} & f_{H j z}\end{array}\right]^{T}\right)$ は手先が受ける反力を 表し, $\boldsymbol{f}_{Z}=\left[\begin{array}{lll}f_{Z x} & f_{Z y} & f_{Z z}\end{array}\right]^{T}, \boldsymbol{\tau}_{Z}=\left[\begin{array}{lll}\tau_{Z x} & \tau_{Z y} & \tau_{Z z}\end{array}\right]^{T}$ は, ZMP でロボットの足裏が受ける力・モーメントを表すべクトルであ る。なお，図ではモーメントを二重矢印で表している， $\boldsymbol{I}_{i}, \boldsymbol{\omega}_{i}$ はそれぞれ第 $i$ リンクの基準座標系に関する慣性テンソル，角 速度べクトルを表す。

まず，ヒューマノイドロボットの手先が対象物から反力を受 けない場合の ZMP について定式化を行う．ZMP とは足裏と床 との支持領域における圧力中心であり，ZMP でロボットが受け る力 $\left(\boldsymbol{f}_{Z}\right) \cdot$ モーメント $\left(\boldsymbol{\tau}_{Z}\right)$ は次式により定式化される.

$$
\begin{aligned}
\boldsymbol{f}_{Z} & =M\left(\ddot{\boldsymbol{p}}_{G}-\boldsymbol{g}\right) \\
\boldsymbol{\tau}_{Z} & =\dot{\boldsymbol{L}}_{G}+M\left(\boldsymbol{p}_{G}-\boldsymbol{p}_{Z}\right) \times\left(\ddot{\boldsymbol{p}}_{G}-\boldsymbol{g}\right)
\end{aligned}
$$

ここで, $M=\sum_{i=1}^{n} m_{i}$ はロボットの質量, $\boldsymbol{g}=\left[\begin{array}{lll}0 & 0 & -g\end{array}\right]^{T}$ は 重力ベクトルを表す.また， $\boldsymbol{L}_{G}\left(=\left[\begin{array}{lll}L_{G x} & L_{G y} & L_{G z}\end{array}\right]^{T}\right)$ は重心 まわりの角運動量を表し，

$$
\boldsymbol{L}_{G}=\sum_{i=1}^{n}\left\{m_{i}\left(\boldsymbol{p}_{i}-\boldsymbol{p}_{G}\right) \times \dot{\boldsymbol{p}}_{i}+\boldsymbol{I}_{i} \boldsymbol{\omega}_{i}\right\}
$$

と定義される。式 $(2)$ に $\tau_{Z x}=\tau_{Z y}=0$ を代入し， $\boldsymbol{p}_{Z}$ につ いて解くことにより，手先に反力を受けない場合の ZMP の位 置は次式により求められる.

$$
\begin{aligned}
& x_{Z}=\frac{-\dot{L}_{G y}+M x_{G}\left(\ddot{z}_{G}+g\right)-M\left(z_{G}-z_{Z}\right) \ddot{x}_{G}}{M\left(\ddot{z}_{G}+g\right)} \\
& y_{Z}=\frac{\dot{L}_{G x}+M y_{G}\left(\ddot{z}_{G}+g\right)-M\left(z_{G}-z_{Z}\right) \ddot{y}_{G}}{M\left(\ddot{z}_{G}+g\right)}
\end{aligned}
$$

次に，手先が対象物と接触することにより，反力を受ける ヒューマノイドロボットの ZMP について考える，ZMP で 


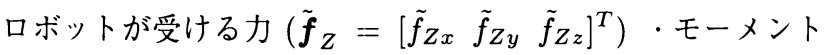

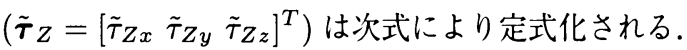

$$
\begin{aligned}
\tilde{\boldsymbol{f}}_{Z}= & M\left(\ddot{\boldsymbol{p}}_{G}-\boldsymbol{g}\right)-\sum_{j=1}^{2} \boldsymbol{f}_{H j} \\
\tilde{\boldsymbol{\tau}}_{Z}= & \dot{\boldsymbol{L}}_{G}+M\left(\boldsymbol{p}_{G}-\tilde{\boldsymbol{p}}_{Z}\right) \times\left(\ddot{\boldsymbol{p}}_{G}-\boldsymbol{g}\right) \\
& -\sum_{j=1}^{2}\left(\boldsymbol{p}_{H j}-\tilde{\boldsymbol{p}}_{Z}\right) \times \boldsymbol{f}_{H j}
\end{aligned}
$$

手先に反力を受けないロボットの場合と同様に, 式（7）に $\tilde{\tau}_{Z x}=\tilde{\tau}_{Z y}=0$ を代入し, $\tilde{\boldsymbol{p}}_{Z}$ について解くことにより, 手 先に反力を受ける場合の ZMP の位置は次式により求められる.

$$
\begin{aligned}
\tilde{x}_{Z}= & \frac{-\dot{L}_{G y}+M x_{G}\left(\ddot{z}_{G}+g\right)-M\left(z_{G}-z_{Z}\right) \ddot{x}_{G}}{M\left(\ddot{z}_{G}+g\right)-\sum_{j=1}^{2} f_{H j z}} \\
& -\frac{\sum_{j=1}^{2}\left\{x_{H j} f_{H j z}-\left(z_{H j}-z_{Z}\right) f_{H j x}\right\}}{M\left(\ddot{z}_{G}+g\right)-\sum_{j=1}^{2} f_{H j z}} \\
\tilde{y}_{Z}= & \frac{\dot{L}_{G x}+M y_{G}\left(\ddot{z}_{G}+g\right)-M\left(z_{G}-z_{Z}\right) \ddot{y}_{G}}{M\left(\ddot{z}_{G}+g\right)-\sum_{j=1}^{2} f_{H j z}} \\
& -\frac{\sum_{j=1}^{2}\left\{y_{H j} f_{H j z}-\left(z_{H j}-z_{Z}\right) f_{H j y}\right\}}{M\left(\ddot{z}_{G}+g\right)-\sum_{j=1}^{2} f_{H j z}}
\end{aligned}
$$

\section{2 手先反力と ZMP の関係}

式 (8)，（9）から，それぞれ式 (4)，(5) を引くことにより, 次式が得られる.

$$
\begin{aligned}
& \Delta x_{Z}=\sum_{j=1}^{2} \frac{\left(z_{H j}-z_{Z}\right) f_{H j x}+\left(\tilde{x}_{Z}-x_{H j}\right) f_{H j z}}{M\left(\ddot{z}_{G}+g\right)} \\
& \Delta y_{Z}=\sum_{j=1}^{2} \frac{\left(z_{H j}-z_{Z}\right) f_{H j y}+\left(\tilde{y}_{Z}-y_{H j}\right) f_{H j z}}{M\left(\ddot{z}_{G}+g\right)}
\end{aligned}
$$

ここで, $\Delta x_{Z}=\tilde{x}_{Z}-x_{Z}, \Delta y_{Z}=\tilde{y}_{Z}-y_{Z}$ である. 式 (10), （11）の物理的意味を考えてみよう. 式 (10)，（11）は，手先に 反力が加わることにより, ヒューマノイドロボットの ZMP の位 置が $\Delta x_{Z}, \Delta y_{Z}$ だけ変位することを示している．簡単な例によ り考えてみる. Fig. 3 (a) に示すように地面からの高さが一定 $\left(z_{H}\right)$ で質量 $M$ の倒立振り子を仮定する. この倒立振り子が直 立した状態で, 水平方向に外力 $f$ を受けるとする (Fig. 3(b)). このとき, 支点が $\Delta x_{Z}=\frac{z_{H} f}{M g}$ だけ, 反力を受ける方向にずれ ることで, 倒立振り子は力の釣り合いを保つことができる．こ の倒立振り子の支点の移動量が, 式 (10), (11) のZMP の変 位量に相当する.

つまり，手先に反力が加わらないと仮定して生成した歩行動 作パターンを式 (10)，（11）に従って変更することで, 押し操 作に対する歩行パターンを生成することができる。しかしなが ら, 対象物と床面との摩擦係数を正確に知ることは困難である ため, 手先反力の目標值をあらかじめ計画することも困難であ ると考えられる。 そこで本研究では，式 (10)，（11）において

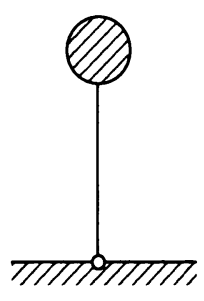

(a) Inverted pendulum without External Force

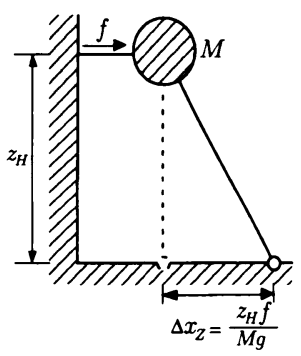

(b) Inverted pendulum with External Force

Fig. 3 Modification of the position of fulcrum

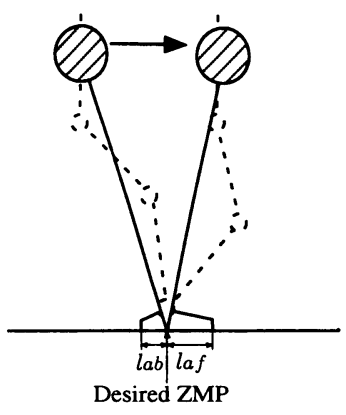

(a) Walking Pattern for a robot whose hands do not contact with an object

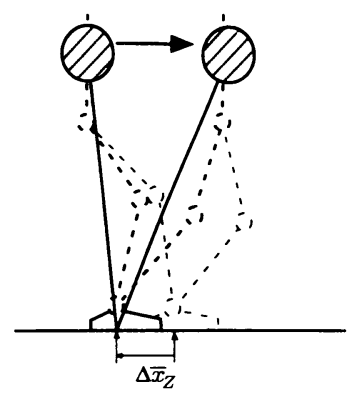

(b) Modification of the desired ZMP
Fig. 4 Modification of the ZMP position

目標 ZMP の位置の変更量を一定とする，以降の議論において は, 目標 ZMP の変更量が一定であることを明示するため, 変 更量を $\Delta \bar{x}_{Z}, \Delta \bar{y}_{Z}$ と記述する.

次に，ヒューマノイドが対象物の押し操作を行いながら歩行 することを考える，ロボットの進行方向は $x$ 方向であるとする. また，手先は水平方向に反力を受け，胴体も水平面内に拉いて のみ摇動すると仮定する。この摇動の影響により手先反力も変 動し, その結果としてZMP の位置にずれが生じる. 歩行は単 脚支持相と両脚支持相が交互に生じるため, 動的平衡を保つた めには，手先反力の変動が次式のように設定された範囲に収ま ることが必要である。

$$
\begin{aligned}
M g\left(\Delta \bar{x}_{Z}-l_{a f}\right) & \leq \sum_{j=1}^{2}\left(z_{H j}-z_{Z}\right) f_{H j x} \\
& \leq M g\left(\Delta \bar{x}_{Z}+l_{a b}\right)
\end{aligned}
$$

ここで, $l_{a f}, l_{a b}$ の定義はFig.4 に示されており，それぞれ，目 標 ZMP からつま先 $\left(l_{a f}\right)$ まで, ならびに踵 $\left(l_{a b}\right)$ までの距離を 表す. 式（12）より足裏支持領域が大きく，かつ対象物と接触す る手先位置 $\left(z_{H j}-z_{Z}\right)$ が低い方が, 広範囲の手先反力に対して ロボットは動的平衡を維持できることが分かる．なお，予期せ 対象物の動作により接触が離れる場合に備えるため, 式 (12) には $f_{H 1 x}=f_{H 2 x}=0$ の場合が含まれるべきである。これは， $\Delta \bar{x}_{Z}$ に対して $-l_{a b}<\Delta \bar{x}_{Z}<l_{a f}$ のような制限を与える.

次に, 手先反力を仮定せずに生成した歩行動作パターンにおい て目標 ZMP の位置を一定量 $\Delta \bar{x}_{Z}, \Delta \bar{y}_{Z}$ だけ変更して, ヒュー マノイドロボットによる押し操作に適用した場合を考える。この 
歩行動作パターンは対象物の運動の影響を考慮していない。つ まり，対象物が遅い速度で動いているにもかかわらずロボット が速い速度で歩行する場合や，その逆の場合が考えられる。し かし, 本研究では押し操作を実行中に対象物の予期せ女運動に より手先反力が 0 になった場合でも，ロボットは動的平衡を維 持できるようにしているため，ロボットが対象物よりも速い速 度で歩行する場合のみを除外することを考える，計画された歩 行パターンにおいて, 歩行速度が対象物の速度を上回ると, 手 先と対象物の間で滑りが生じた場合などに，ロボットが対象物 に近づきすぎることで姿勢が立ち，転倒に結びつくことになる． ロボットのアームを固定し，ロボットの動作が倒立振り子で近 似でき，かつ対象物と床面との摩擦係数が既知の場合，付録に 示す定式化を用いることにより，対象物とロボットの相対位置 の変化量 $\delta x$ は次式により表すことができる.

$$
\begin{aligned}
\delta x(t)= & x_{G}(0)\left\{\cosh \left(\frac{t}{T_{b}}\right)-\cosh \left(\frac{t}{T_{c}}\right)\right\} \\
& +\dot{x}_{G}(0)\left\{T_{b} \cosh \left(\frac{t}{T_{b}}\right)-T_{c} \cosh \left(\frac{t}{T_{c}}\right)\right\} \\
& +\frac{\mu M_{O} z_{G}}{M}\left\{1-\cosh \left(\frac{t}{T_{b}}\right)\right\}-\Delta \bar{x}_{Z}\left\{1-\cosh \left(\frac{t}{T_{c}}\right)\right\}
\end{aligned}
$$

ここで， $\mu$ は対象物と床面との摩擦係数， $M_{o}$ は対象物の質量 を表し， $T_{c}=\sqrt{z_{G} / g}, T_{b}=\sqrt{\left(M+M_{O}\right) /(M g)}$ である。ロ ボットが押し操作において, 動的平衡を保つためには，ロボット の歩行速度が対象物の速度を超えない，つまり $\delta x \geq 0$ が成立す ることが必要である。以上の解析をもとに本研究では, ヒュー マノイドロボットによる押し操作において目標 ZMP の修正量 $\Delta \bar{x}_{Z}$ をシミュレーションに基づいて見積もることにする.

本章の最後に，ロボットが転倒する場合に関する考察を行う. 我々は文献 [18] においてヒューマノイドロボットの手先が対象物 や環境と接触する場合の ZMP に関する解析を行った。 その中で, ヒューマノイドロボットの手先が環境と接触する場合の ZMP として一般化 ZMP を提案し, その安定領域を導いた。 ヒュー マノイドロボットによる押し操作の場合, ZMP が足裏支持領 域の端に来た場合でも，ロボットは必ずしも転倒するとは限ら ない. 例えば, Fig. 5 に示すように対象物を強い力で押した結 果, ZMP が踵に存在する場合を考える。この場合でも，ZMP

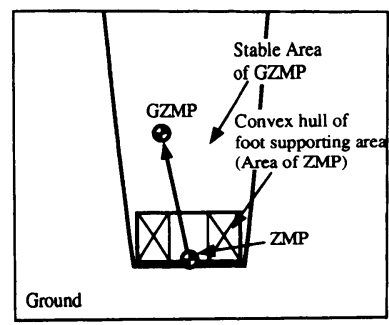

(a) Area of two ZMPs

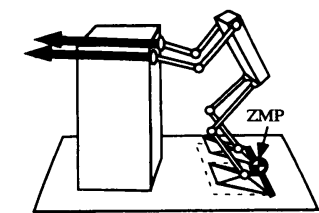

(b) Robot keeps the statical balance
Fig. 5 Relationship between ZMP and Generalized ZMP(GZMP)

†目標 ZMP の修正量を見積もるには, 摩擦係数 $\mu$ の値を知る必要があ る. 実際は摩擦係数の正確な值を得ることは困難であり, 手先に備えら れたカセンサの值等より大まかな値を見積もらなくてはならない.
で発生する床反力と手先が対象物から受ける反力が釣り合うこ とで，ロボットは転倒しないことが考えられる。しかしながら 本研究では, 対象物の予期せぬ運動により, 手先と対象物の接 触が離れる場合も考慮に入れ，ZMP が足裏支持領域に含まれ るように，動作の計画を行う。

\section{4. シミュレーション}

4. 1 コントローラ

シミュレーションに用いた歩行制御系の概要を Fig. 6 に示 す.まず手先反力を考慮せずに, 線形倒立振子モード [11] [12] に基づく動歩行パターンが与えられているとする．続いて，手 先が対象物から受ける反力を考慮するため, 目標 ZMPを $\Delta \bar{x}_{Z}$ だけずらす，さらに，実際に歩行を行う場合は，胴体の姿勢制 御と ZMP の制御を両立させる安定化制御系を導入する.

\section{2 シミュレーション結果}

HRP [3] において開発されたシミュレーションソフトウェ ア OpenHRP [19] [20] を用いて, 押し操作のシミュレーショ ンを行った. ヒューマノイドロボットのモデルとしては, HRP$2 \mathrm{P}$ [4] を用いた. HRP-2P は背丈が $H=1.54[\mathrm{~m}]$ で, 重量が $M=58[\mathrm{~kg}]$ のロボットである. また, 足に関するパラメー夕は 仮に $l_{a f}=0.1[\mathrm{~m}], l_{a b}=0.08[\mathrm{~m}]$ とおいた. 対象物としては $M_{O}=4[\mathrm{~kg}]$ の箱を用い, 床面と箱との間の摩擦係数は $\mu=0.5$ に設定した。

押し操作において，アームは固定した。この場合，押し操作さ れる対象物は加速・減速を繰り返すことが予想される。つまり， 付録において対象物が等速運動する場合の議論をもとに， $x$ 方 向における目標 ZMP の修正量は $\Delta \bar{x}_{Z}=0.03 \cong \mu M_{O} z_{G} / M$ としだ。また, $z_{H 1}-z_{Z}=z_{H 2}-z_{Z}=0.67[\mathrm{~m}]$ とした.こ のとき, 与えられた $\Delta \bar{x}_{Z}$ が式（12）を満足するかどうか調べ るため, 式 (12) の各項を計算した. その結果を Table 1 に示 す.この計算結果によると, $\Delta \bar{x}_{Z}=0.03, \Delta \bar{x}_{Z}=0$ 両方の場 合において，与えられた姿勢に対してロボットは, 手先反力が $10[\mathrm{~N}]$ 程度の範囲で変動しても動的平衡を保てることになる.

次に, ロボットの歩行速度と対象物の速度との䛊差を吟味す るため, 式 (13) を $\Delta \bar{x}_{Z}=0.03, \Delta \bar{x}_{Z}=0.0$ 両方の場合に

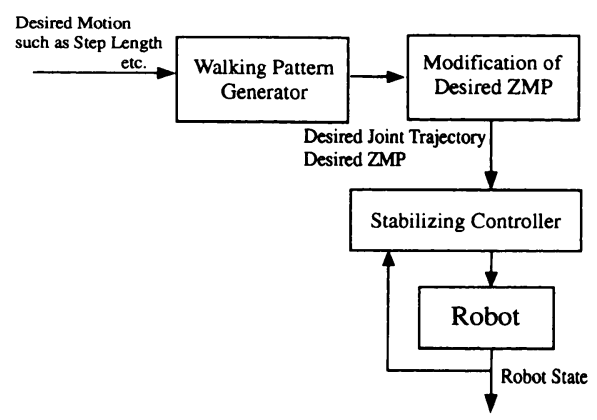

Fig. 6 Overview of the controller

Table 1 Result of calculation

\begin{tabular}{|c|c|c|}
\hline & $M g\left(\Delta \bar{x}_{Z}-l_{a f}\right)$ & $M g\left(\Delta \bar{x}_{Z}+l_{a b}\right)$ \\
\hline$\Delta \bar{x}_{Z}=0.03$ & -39.79 & 62.52 \\
\hline$\Delta \bar{x}_{Z}=0.0$ & -56.84 & 45.47 \\
\hline
\end{tabular}




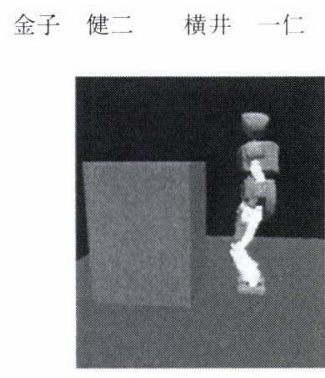

(a) $t=2.25[\mathrm{sec}]$

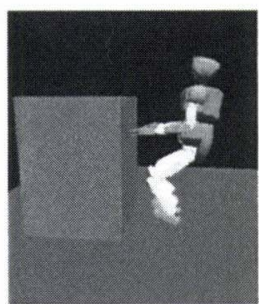

(c) $t=7.5[\mathrm{sec}]$

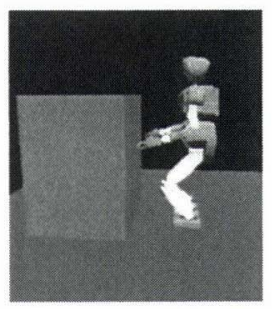

(b) $t=4.50[\mathrm{sec}]$

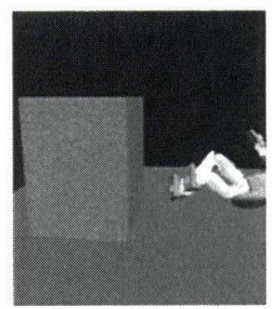

(d) $t=8.25[\mathrm{sec}]$

Fig. 10 Simulation result $(\Delta x=0.0)$

(a) $t=2.25[\mathrm{sec}]$

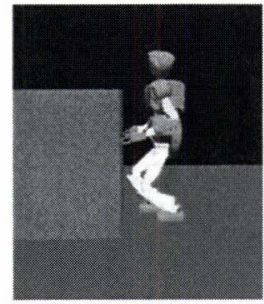

(d) $t=9.0[\mathrm{sec}]$

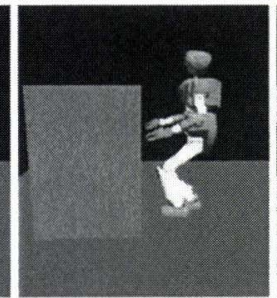

(b) $t=4.50[\mathrm{sec}]$

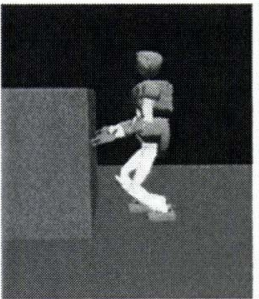

(e) $t=11.25[\mathrm{sec}]$ (c) $t=6.75[\mathrm{sec}]$

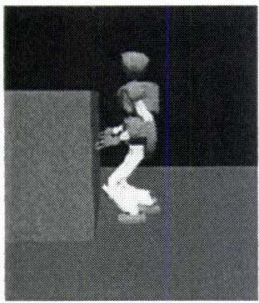

(f) $t=13.5[\mathrm{sec}]$

Fig. 8 Simulation result $(\Delta x=0.03)$

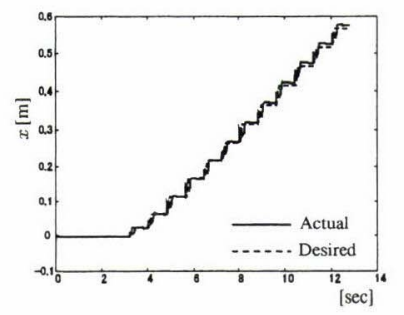

(a) ZMP in the $\mathrm{x}$ direction

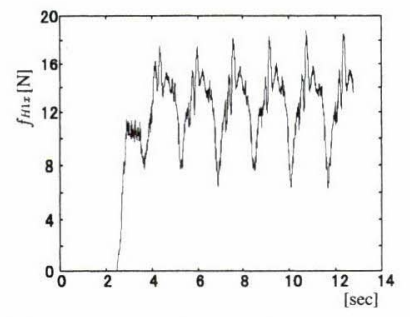

(c) Reaction force of the right hand in the $\mathrm{x}$ direction

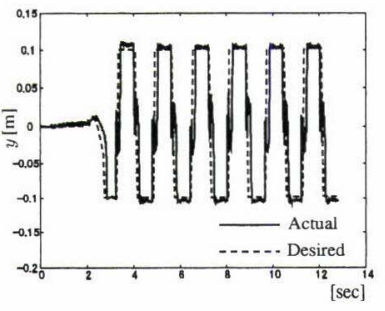

(b) ZMP in the $y$ direction

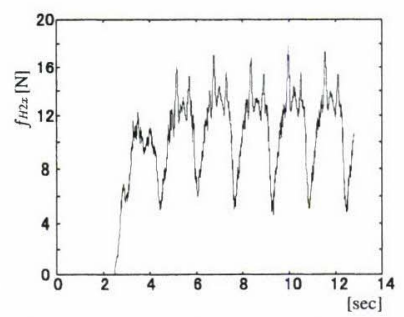

(d) Reaction force of the left hand in the $\mathrm{x}$ direction

Fig. 9 ZMP position and hand reaction force $(\Delta x=0.03)$

対して計算した。まず，式（A.2）を用いることにより，手先反 力を考慮せずに生成した歩行動作パターンを Fig. 7 (a) に示す. 歩行動作パターンとしては, 静止した状態から歩き始め, 定常 歩行に移行するまでの 2 歩を考えた。式（13）を計算した結果

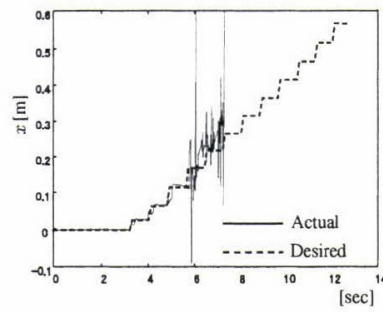

(a) ZMP in the $\mathrm{x}$ direction

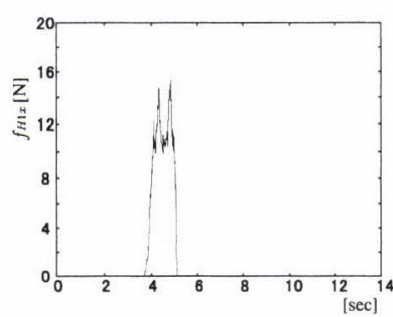

(c) Reaction force of the right hand in the $\mathrm{x}$ direction

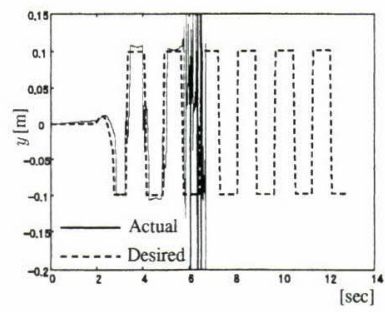

(b) ZMP in the y direction

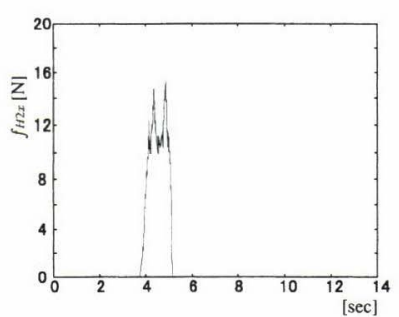

(d) Reaction force of the left hand in the $\mathrm{x}$ direction

Fig. 11 ZMP position and hand reaction force $(\Delta x=0.0)$

を Fig. 7 (b) に示す. 図に示すように, $\Delta \bar{x}_{z}=0.03$ の場合は歩 行速度と対象物の速度の誤差は小さいが, $\Delta \bar{x}_{z}=0.0$ の場合は 歩行速度が対象物の速度を上回っており，押し操作が続行でき ない場合が存在するのではないかと予想できる.

実際にロボットにより押し操作を行った場合の結果を Fig. 8 Fig. 11 に示す. Fig. 8,9 には $\Delta \bar{x}_{Z}=0.03$ と扔いた場合の押 し操作の結果を示しており, Fig. 10，11には $\Delta \bar{x}=0.0$ とおい た場合の結果を示す。図に示すように, $\Delta \bar{x}_{Z}=0.03$ と扔いた 場合，ロボットは動的平衡を保ちつつ押し操作を実現している ことが分かる。そそれに対して， $\Delta \bar{x}_{Z}=0.0$ の場合は，手先と対 象物との間で滑りが生じて，ロボットが対象物に対して近づい た結果，転倒が生じていることが分かる. 


\section{5. 拡}

張

前章までに抢ける押し操作は，手先反力を仮定せずに生成し た歩行動作パターンにおいて目標 ZMP を一定量変更するもの であった。次に，より安定に押し操作を行うことを目指してア ルゴリズムを拡張することを考える。

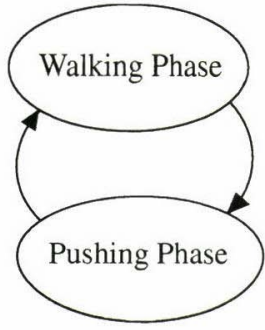

(a) Explanation of the extended method

Fig. 12 Extension of the pushing controller

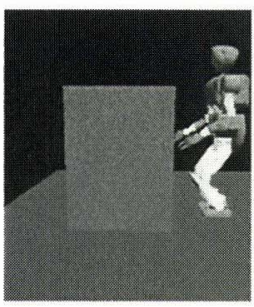

(a) $t=1.5[\mathrm{sec}]$

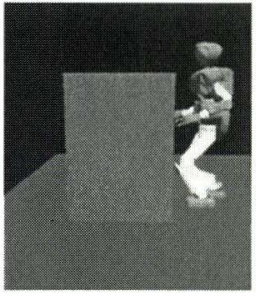

(d) $t=5.25$ (Walk)

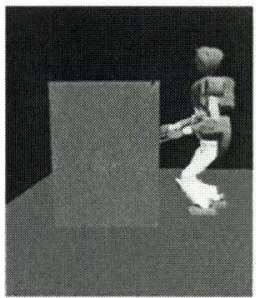

(g) $t=7.5$ (Push)

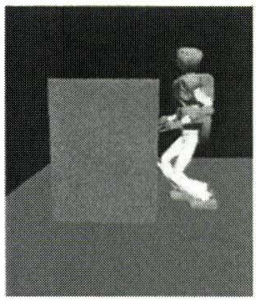

(j) $t=9.75$ (Walk

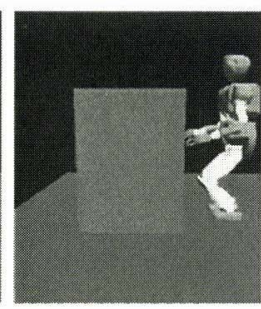

(b) $t=3.75$ (Walk)

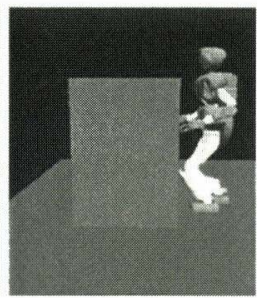

(e) $t=6$ (Push)

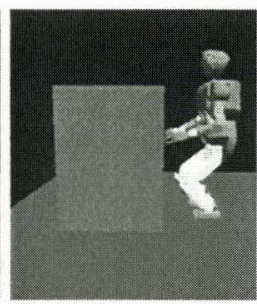

(h) $t=8.25$ (Walk)

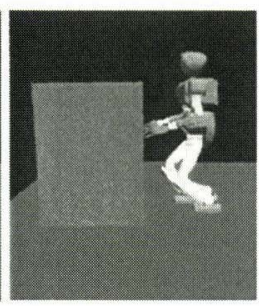

(k) $t=11.25$ (Push)

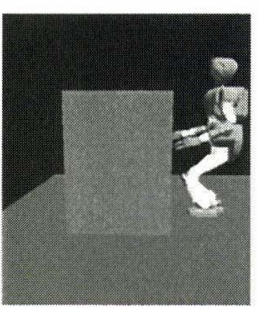

(c) $t=4.5$ (Walk)

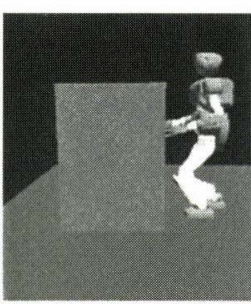

(f) $t=6.75$ (Push)

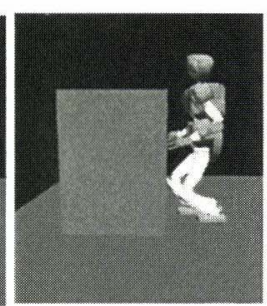

(i) $t=9$ (Walk)

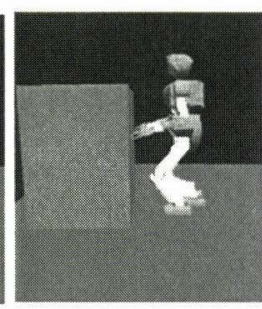

(1) $t=15$ (Walk)
Fig. 13 Simulation result of the extended method
対象物を押しながら歩行する場合，両脚支持期と比較して片 脚支持期の方がロボットに加わる予期せ好外乱によって転倒す る可能性が高くなることが予想できる。つまり，実際に実機で 押し操作を行う場合等, 予期せ妏対象物の運動に対処するため, 歩行するフェーズと押し操作を行うフェーズを分離することが 考えられる (Fig. 12 (a))。この手法では, まず片足を踏み出 す。次に，两脚支持期にアームを制御することにより対象物の 押し操作を行う。さらに, 押し操作により対象物が移動した分 だけ，後ろ側にある足を踏み出すことにする。両脚支持期に押 し操作を行うため, 片足のみが床面と接触する場合と比較して, より大きな手先反力に対して ZMP のマージンをとることが可 能である (Fig. 12 (b)).

この手法によりシミュレーションを行った結果を Fig. 13 に 示す．前章までの方法と比較して対象物を押す速度は遅いが, 片 脚支持期に対象物を押していない点が特徴である。

\section{6. 結言}

本論文では, ヒューマノイドロボットによる押し操作につい て議論した，手先反力を考慮せずに生成した歩行動作パターン において目標ZMP を一定量だけ变更することで，押し操作に 対する歩行パターンとすることを考えた。この歩行動作パター ンに対して，ロボットが動的平衡を保てるかどうかを，ZMP と 歩行速度の観点より解析した。ささらに, 対象物を押すフェーズ と歩くフェーズを分離する手法についても議論した，

現在，押し操作の実機実験による検証を行っており，次報で 結果を紹介する予定である。最後に，本研究を進めるに当たり， 第一著者が有意義な議論をいただいた，広島大学の金子真教授 に感謝します。

\section{参 考 文 献}

[1]井上, 石井, 大川：“腕で作業をしながら移動する人間型ロボットの 実時間制御”, 日本ロボット学会誌, vol.18, no.1, pp.75-86, 2000.

[2] H. Yoshida, K. Inoue, T. Arai and Y. Mae: "Mobile Manipulation of Humanoid Robots-Optimal Posture for Generating Large Force Based on Statics -," Proc. of 2002 IEEE Int. Conf. on Robotics and Automation, pp.2271-2276, 2002.

[3] H. Inoue et al.: "HRP: Humanoid Robotics Project of MITI," The First IEEE-RAS Int. Conf. on Humanoid Robots, 2000.

[4] K. Kaneko et al.: "Design of Prototype Humanoid Robotics Platform for HRP," Proc. of IEEE/RSJ Int. Conf. Intelligent Robots and Systems, 2002.

[5] K. Yokoyama, H. Hand, T. Isozumi, Y. Fukase, K. Kaneko, F. Kanehiro and Y. Kawai: "Cooperative Works by a Human and a Humanoid Robot," Proc. of 2003 IEEE Int. Conf. on Robotics and Automation, 2003.

[6] F. Kanehiro et al.: "The First Humanoid Robot that has the Same Size as a Human and that can Lie down and Get up," Proc. of 2003 IEEE Int. Conf. on Robotics and Automation, 2003.

[ 7 ] K. Hirai, M. Hirose, Y. Haikawa and T. Takenaka: "The Development of Honda Humanoid Robot," Proc. of 1998 IEEE Int. Conf. on Robotics and Automation, pp.1321-1326, 1998.

[8] 竹中：脚式移動ロボットの姿勢制御装置, 特開平 10-230485, 1998.

[9] 北川, 長阪, 西脇, 稻葉, 井上：“遺伝的アルゴリズムを用いた人間 型ロボットの脚腕協調動的起立動作の生成”，第 17 回日本ロボット 学会学術講演会予稿集, pp.1191-1192, 1999.

[10] 高西：“上体の運動によりモーメントを補償する 2 足歩行ロボット”, 
日本ロボット学会誌, vol.11, no.3, pp.348-353, 1993.

[11] S. Kajita, T. Yamaura and A. Kobayashi: "Dynamic Walking Control of a Biped Robot Along a Potential Energy Conserving Orbit," IEEE Trans. on Robotics and Automation, vol.8, no.4, pp.431-438, 1992.

[12] S. Kajita, O. Matsumoto and M. Saigo: "Real-time 3D Walking Pattern Generation for a Biped Robot with Telescopic Legs," Proc. of 2001 IEEE Int. Conf. on Robotics and Automation, pp.2299-2036, 2001.

[13] K. Nishiwaki, T. Sugihara, S. Kagami, M. Inaba and H. Inoue: "Online Mixture and Connection of Basic Motions for $\mathrm{Hu}$ manoid Walking Control by Footprint Specification," Proc. of 2001 IEEE Int. Conf. on Robotics and Automation, pp.4110$4115,2001$.

[14] K. Nishiwaki, S. Kagami, Y. Kuniyoshi, M. Inaba and H. Inoue: "Online Generation of Humanoid Walking Motion based on a Fast Generation method of Motion Pattern that Follows Desired ZMP," Proc. of 2002 IEEE/RSJ Int. Conf. on Intelligent Robots and Systems, pp.2684-2689, 2002.

[15] M.T. Mason and J.K. Salisbury: Robot Hands and the Mechanics of Manipulation. MIT Press, Cambiridege MA, 1985.

[16] K.M. Lynch: "The Mechanics of Fine Manipulation by Pushing," Proc. of IEEE Int. Conf. on Robotics and Automation, pp.2269-2276, 1992.

[17] K. Harada, J. Nishiyama, Y. Murakami and M. Kaneko: "Pushing Multiple Objects using Equivalent Friction Center," Proc. of 2002 IEEE Int. Conf. on Robotics and Automation, pp.2485$2491,2002$.

[18] 原田, 梶田, 金広, 藤原, 金子, 横井, 比留川: “ヒューマノイドロ ボットの脚腕協調における ZMP 解析”, 日本機械学会ロボティクス メカトロニクス講演会講演論文集, 2003.

[19] F. Kanehiro et al.: "Virtual humanoid robot platform to develop controllers of real humanoid robots without porting," Proc. of IEEE/RSJ Int. Conf. on Intelligent Robots and Systems, 2001.

[20] H. Hirukawa et al.: "OpenHRP: Open Architecture Humanoid Robot Platform," Proc. of Int. Symp. on Robotics Research. 2001.

\section{付録 A. 歩行パターンの誤差に関する考察}

本章では，手先に反力が加わらないと仮定して導出した歩行 動作パターンにおいて，目標 ZMP を一定量修正した場合を考 える.このとき，倒立振り子モデルを用いて，実際に押し操作 を行う場合にどの程度の䛊差が生じるか吟味する。本章では, 対象物と床面の間の摩擦係数は既知とする。また，簡単のため Saggital Plane 内の運動のみに着目する.まず, Fig. 14 に示 すように振り子の質量を $M$, 床面からの高さを $z_{G}$, 支点からの 水平距離を $x_{G}$ とする。.また対象物を押す場合，対象物の質量 を $M_{O}$, 対象物と床面の間の動摩擦係数を $\mu$ とする. 対象物と 接触を持たない倒立振り子（Fig. 14 (a)）の運動は次式の微分 方程式を満足する [11] [12].

$$
\ddot{x}_{G}=\frac{g}{z_{G}} x_{G}
$$

この式の一般解は次式のとおりである.

$$
x_{G}(t)=x_{G}(0) \cosh \left(\frac{t}{T_{c}}\right)+T_{c} \dot{x}_{G}(0) \sinh \left(\frac{t}{T_{c}}\right)
$$

ここで, $T_{c}=\sqrt{z_{G} / g}$ である. 目標 ZMP を $-\Delta \bar{x}_{Z}$ だけずら

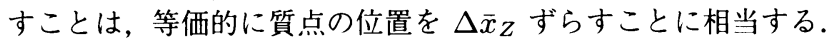

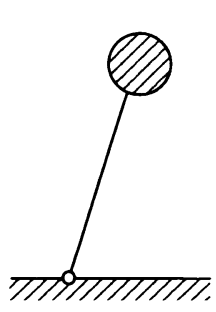

(a) Inverted pendulum without pushing an object

Fig. 14 Inverted pendulum model under pushing

つまり，目標 ZMP をずらした場合の倒立振り子の運動は次式 を満足する。

$x_{G}(t)=\left(x_{G}(0)-\Delta x_{Z}\right) \cosh \left(\frac{t}{T_{c}}\right)+T_{c} \dot{x}_{G}(0) \sinh \left(\frac{t}{T_{c}}\right)+\Delta \bar{x}_{Z}$

次に，倒立振り子が対象物を押している場合を考える (Fig. $14(\mathrm{~b})$ ). このとき, 倒立振り子と対象物の運動はそれぞ れ次式を満足する。

$$
\begin{aligned}
M \ddot{x}_{G} & =\frac{M g}{z_{G}} x_{G}-f \\
M_{O} \ddot{x}_{O} & =-\mu M_{O} g+f
\end{aligned}
$$

ここで，対象物と倒立振り子の質点が距離を一定に保つ場合，こ の式の一般解は次式のとおりである.

$$
\begin{aligned}
x_{G}(t)= & \left(x_{G}(0)-\frac{\mu M_{O} z_{G}}{M}\right) \cosh \left(\frac{t}{T_{b}}\right)+T_{b} \dot{x}_{G}(0) \sinh \left(\frac{t}{T_{b}}\right) \\
& +\frac{\mu M_{O} z_{G}}{M}
\end{aligned}
$$

ここで, $T_{b}=\sqrt{\left(M+M_{O}\right) z_{G} /(M g)}$ である.

式 (A.3) に従って, 手先に反力を受けない倒立振り子の質点 の位置を $\Delta x_{Z}$ だけオフセットさせることで導出された歩行動 作パターンを，ヒューマノイドロボットに与えて押し操作を実現 することを考える．押し操作を行う場合，系の運動は式 (A.6) に従う。つまり，式 (A.3) と式 (A.6) で計算される $x_{G}$ とは 必ずしも一致せず, 誤差が生じる。この誤差を $\delta x(t)$ とすると, これは次式により導出される.

$$
\begin{aligned}
\delta x(t)= & x_{G}(0)\left\{\cosh \left(\frac{t}{T_{b}}\right)-\cosh \left(\frac{t}{T_{c}}\right)\right\} \\
& +\dot{x}_{G}(0)\left\{T_{b} \cosh \left(\frac{t}{T_{b}}\right)-T_{c} \cosh \left(\frac{t}{T_{c}}\right)\right\} \\
& +\frac{\mu M_{O} z_{G}}{M}\left\{1-\cosh \left(\frac{t}{T_{b}}\right)\right\}-\Delta \bar{x}_{Z}\left\{1-\cosh \left(\frac{t}{T_{c}}\right)\right\}
\end{aligned}
$$

また, 手先反力の変動量は式（A.6）を式（A.5）に代入するこ とで，次式により導出できる.

$$
f(t)=\frac{M_{O}}{T_{b}^{2}}\left\{\left(x_{G}(0)-\frac{\mu M_{O} z_{G}}{M}\right) \cosh \left(\frac{t}{T_{b}}\right)\right.
$$




$$
\left.+T_{b} \dot{x}_{G}(0) \sinh \left(\frac{t}{T_{b}}\right)\right\}+\mu M_{O} g
$$

なお，上の解析は倒立振り子の質点と対象物とが一定の距離を 保つと仮定した場合の結果である。仮にアームを制御すること で，対象物を等速運動させることが可能となったとする。この とき, 式 (A.5) で $\ddot{x}_{O}=0$ が成立するため, 位置誤差ならび に手先反力の变動量は次式により導出できる.

$$
\delta x(t)=\left(\frac{\mu M_{O} z_{G}}{M}-\Delta x_{Z}\right)\left\{1-\cosh \left(\frac{t}{T_{c}}\right)\right\}
$$

(A.9)

$$
f=\mu M_{O} g
$$

ここで, $\Delta \bar{x}_{Z}=\mu M_{O} z_{G} / M$ とおくことで, $\delta x(t)=0$ が満足 される、つまり，ヒューマノイドロボットによる押し操作にお いて, 対象物が等速度で運動するようにアームの運動や脚によ る歩行が制御でき, かつ対象物と床面との摩擦係数が正確に分 からている場合, 本研究で提案する目標 ZMP を一定量 $\Delta \bar{x}_{Z} た ゙$ けずらすことで押し操作に対する歩行パターンを生成する手法 は，押し操作に対する正確な歩行パターンとなることが分かる．

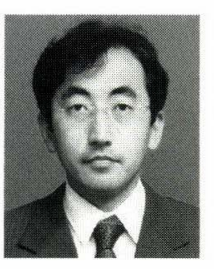

原田研介 (Kensuke Harada)

1968 年 9 月 28 日生. 1997 年 3 月京都大学大学 院工学研究科機械工学専攻博士後期課程修了. 博士 (工学)。同年 4 月広島大学工学部助手, 2002 年 4 月独立行政法人産業技術総合研究所研究員. ヒュー マノイドロボット，ロボットハンド，ロボットマニ ピュレータ等, ロボット機構の力学と制御に関する 研究に興味を持つ. IEEE, 計測自動制御学会, 日本機械学会などの 会員.

(日本ロボット学会正会員)

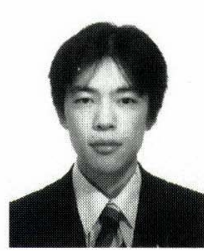

\section{金広文男（Fumio Kanehiro）}

1971 年 7 月 22 日生. 1999 年東京大学大学院工学 系研究科情報工学専攻博士課程修了. 博士 (工学). 1998 年より日本学術振興会特別研究員. 2000 年電 子技術総合研究所入所. 現在産業技術総合研究所知 能システム研究部門研究員.ヒューマノイドロボッ トのシステム構成法, 全身行動制御に興味がある。 IEEE, 人工知能学会, 日本ソフトウエア科学会, 情報処理学会の各 会員.

(日本ロボット学会正会員)

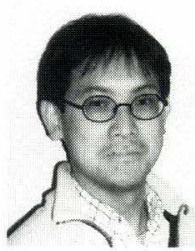

金子健二（Kenji Kaneko）

1965 年 9 月 22 日生. 1990 年慶應義塾大学大学院 理工学研究科電気工学専攻修上課程修了. 同年工業 技術院機械技術研究所に入所. 1995 年 9 月より半 年間米国カーネギーメロン大学客員研究員, 1999 年 9 月より 1 年間仏国 CNRS パリロボット研究 所客員研究員。2001 年より組織改変に伴い独立行 政法人産業技術総合研究所主任研究員, 現在にいたる. 博士 (工学). モーションコントロール, マイクロマシン, 遠隔制御, ヒューマノイ ドロボット等の研究に従事. 日本機械学会, 電気学会の各会員.

(日本ロボット学会正会員)

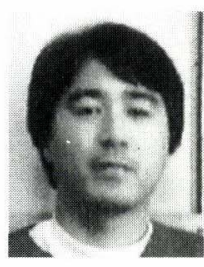

比留川博久 (Hirohisa Hirukawa)

1959 年 1 月 15 日生. 1987 年神户大学大学院自然 科学研究システム科学専攻博士課程修了. 学術博士. 同年通産省工業技術院電子技術総合研究所に入所. 1994 1995 年米国スタンフォード大学計算機科学 科客員研究員. 2001 年改組より独立行政法人産業 技術総合研究所知能システム研究部門ヒューマノイ ド研究グループ長.ロボットの動作計画アルゴリズム, ネットワーク

ロボティクス, ヒューマノイドロボット等の研究に従事.
(日本ロボット学会正会員)

ロボティクス, ヒューマノイドロボット等の研究に従事.
(日本ロボット学会正会員)

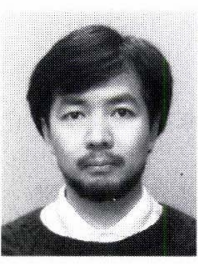

梶田秀司（Shuuji Kajita）

1961 年 1 月 26 日生. 1985 年東京工業大学大学院 修士課程修了 (制御工学専攻)。同年通産省工業技 術院機械技術研究所に入所. 2 足歩行ロボット等の 動的制御技術の研究に従事. 1996 年 2 月より 1 年 間米国カリフォルニア工科大学客員研究員. 2001 年より組織改変に伴い独立行政法人産業技術総合 研究所主任研究員, 現在にいたる。1996 年 3 月東京工業大学より 学位取得 (工学博士). 1996 年度計測自動制御学会論文賞受賞. 計 測自動制御学会, IEEE (Robotics and Automation Society) の会 員.

(日本ロボット学会正会員)

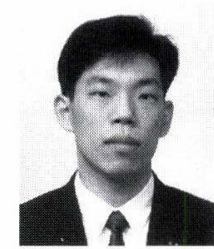

藤原清司（Kiyoshi Fujiwara）

1972 年 4 月 11 日生. 1997 年筑波大学大学院工学 研究科修了. 同年電子技術総合研究所入所. 現在独 立行政法人産業技術総合研究所知能システム部門 ヒューマノイド研究グループ研究員. 生体制御, 医 療福祉工学, マンマシンインタフェース, ヒューマ ノイドロボットなどの研究に従事.

(日本ロボット学会正会員)

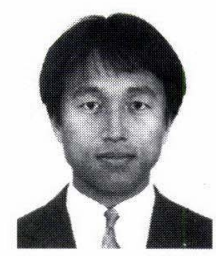

横井一仁（Kazuhito Yokoi）

1961 年 11 月 11 日生. 1986 年東京工業大学大学 院機械物理工学専攻修了. 博士 (工学)。1986 年工 業技術院機械技術研究所に入所. 1995 1996 年又 タンフォード大学客員研究員. 2001 年産業技術総 合研究所知能システム研究部門主任研究員. 神奈 川工科大学連携大学院助教授, 東京工業大学非常勤 講師併任. 人間協調・共存型ロボットシステムプロジェクトに従事. IEEE, 日本機械学会会員.

(日本ロボット学会正会員) 